\title{
Environmental technology and a multiple approach of competitiveness
}

\author{
Milad Abdelnabi Salem ${ }^{1 *}$, Fekri Shawtari ${ }^{1}$, Hafezali Bin Iqbal Hussain ${ }^{2}$ and Mohd Farid Shamsudin ${ }^{3}$
}

\begin{abstract}
This paper investigates the relationships between environmental technology and competitiveness focusing on 224 industrial corporations. To date, there is still a debate regarding the benefits of being green. Previous literature has investigated this relationship mostly in developed countries. Additionally, the majority of these studies do not disaggregate the environmental practices and competitiveness. Less attention has been given to the environmental issues in developing countries. This study aims to fill these gaps by breaking down the environmental technology into two processes and products-focused practices and investigating their effects on the multiple approaches of competitiveness represented by image-, profits-, and satisfaction-related aspects of competitiveness. The study adopts a crosssectional study using a self-reported questionnaire. The collected data are analysed using structural equation modelling technique based on AMOS methods. The results revealed that only products-focused practices could improve the three dimensions of competitiveness. The processes-focused practices did not contribute to any of the competitiveness aspects. Such results provide new insight for the application of resource-based view theory in green-based developing countries.
\end{abstract}

Keywords: Environmental technology, Industrial sector, Competitiveness, Structure equation modelling

\section{Introduction}

Competitiveness reflects the match between the change in the surrounding environment and internal capabilities of corporations [48]. Companies use their tangible and intangible resources to promote their competitive position $[97,98]$ since they reflect the weaknesses and strengths of the corporations [33].

Resources, directly and indirectly, support corporations in improving their competitiveness $[15,16,48,51$, $72,79,97]$. It is commonly known that environmental technology could be a source of competitiveness [24, 48, $63,85,88,92]$. Environmental technology means using raw materials that have low environmental impact, processing them efficiently, and promoting reutilisation and minimal waste of their final products, thus changing the products and processes of a given production cycle [32]. The environmental technologies aim to reduce negative

\footnotetext{
*Correspondence: Milad.Salem@ccq.edu.qa

${ }^{1}$ Community College of Qatar, Doha, Qatar

Full list of author information is available at the end of the article
}

impacts of company's products and services on the environment [12, 44, 57, 90]. Processes- and productsfocused practices are interrelated because engaging in pollution prevention activities requires the consideration of both the products and the processes for manufacturing [12].

Nevertheless, several studies suggest addressing the two concepts in a separated fashion [21, 24, 41, 57, 58]. Klassen and Whybark [57] stated that activities related to products process include pollution prevention technologies, which require adaptation in both processes- and products-focused practices.

\section{Methods}

This study relies on resource-based view theory in developing the framework of the study. The researchers have reviewed the related articles to build the hypotheses of the study. The study adopted a cross-sectional survey method, which means the data are collected at one point in time. A survey method is an appropriate tool when the researcher aims to collect data on particular attributes 
and opinions of a population, and these data are unavailable in secondary sources $[29,96]$. The following sections discuss the literature review and the methodology of the study.

\section{Literature review}

This review focuses on the literature that pertains to the concepts that form the theoretical frame of this paper. By and large, outside of definitions, it elucidates what we currently know about green technology and its relationship with organisational performance according to the resources based view.

\section{Green technology}

Green technology refers to the activities related to both products and processes practices. Processes-focused practices refer to activities that intend to install a greater sense of environmental protection in the production processes. This involves measuring things such as using less polluting inputs, redesigning production processes to be less polluting, and recycling products $[24,48,85$, 88, 92]. Christmann [24] noted that such practices could be divided into pollution prevention and innovation of environmental technology. Klassen and Whybark [57] pointed out that process adaption refers to the fundamental changes to the manufacturing process that reduce any negative impacts on the environment during material acquisition, production, or delivery. Additionally, González-Benito and González-Benito [41] provided a detailed picture of such practices, classifying processesfocused practices into internal processes-related practices and external processes-related practices.

Internal processes practices consider such things as the installation of emission filters or waste separation, installation preparation systems, acquisition of clean technology, using the renewable resource of energy, and concentration of environmental criteria for production planning, while the external processes practices refer to the activities that consider aspects related to the distribution and supply actions. Such activities can be reflected in the purchase of ecological products, incorporation of environmental performance criteria in supplier selection processes, consolidation of shipments, using cleaner transportation methods, and the establishment of recuperation and recycling systems.

Products-focused practices are related to product aspects aiming to design or develop more environmentally friendly products [21], which include things such as redesigning product packaging and products to be more environmentally responsible, developing new environmentally responsible products, and advertising the environmental benefits of the production [21, 28, 57, 88]. González-Benito and González-Benito [41] classified the products-focused practices into several dimensions, namely using alternative materials that reduce pollution and hazard, reducing resource consumption, designing for disassembly, designing the product in a manner enabling the reusability and recyclability of the product, remanufacturing, and disposal. As a result, productsfocused practices intend to make production or the goods less damaging to the environment, which gives extra value to these products or goods. Klassen and Whybark [57] identify such practices as all investments that significantly modify an existing product's design to reduce any negative impacts on the environment during any stage of product manufacturing, using, disposing, and reusing.

In general, products- and processes-focused practices can be captured by several indicators that have been widely used by previous literature. These include things such as substituting polluting and hazardous materials/ parties with environmentally friendly materials/parties; designing products with a constant focus on reducing resource consumption and waste reduction; designing products that are dismantled, reused, and recycled; preferring green products in purchasing, consolidating the shipments; selecting cleaner transportation methods; using recyclable and reusable packaging/containers in logistics; implementing cleaner processes and technologies; and adopting recuperation and recycling systems (e.g. $[28,41,58,76,87,88])$.

\section{Green technology and competitiveness}

Despite the high cost of products- and processes-focused green practices, some historical examples have shown that behaving in an environmentally friendly way could save companies additional costs such as costs related to cleaning up their waste and loss of natural resources. For example, replacing its non-environmentally friendly parts by 3M Pharmaceutical Corporation in California imposed cost of $\$ 60,000$. However, it removed the corporation annual solvent purchase of $\$ 15,000$ and the need for $\$ 180,000$ in emission control equipment. Additionally, it protected the environment since it eliminated around 24 tons of air pollution from the California atmosphere [62]. Shrivastava [90] found that focusing on green technological practices could benefit both the surrounding environment and competitiveness.

Similar results are articulated in environmental literature $[24,41,54,57,60,76,82,85,90]$. Porter and Van der Linde [73] emphasised that environmental innovation can be a means to improve the competitiveness of corporations. Such innovation has been found to have a direct relationship with corporate competitiveness [28]. Rubashkina et al. [80] concluded that environmental regulations have a positive influence on the output of 
innovation activity represented by patents of European manufacturing sectors, which is considered support of Porter's model. Additionally, Shrivastava [90] found that adoption of environmental technology can improve the public image of the corporation, which can be considered an aspect of competitiveness. Although Shrivastava considered one aspect of competitiveness represented by the public image to be a result of environmental technology practices, the findings provide indicators that such practices can improve the competitiveness of the corporation. Additionally, eco-design as products-focused practices were found to be significantly related to cost reduction [100], and the same relationship was observed with reverse logistics [35]. Also, such a relationship was observed in the study of Lin et al. [60] that investigated the relationships between market demand, green products, and corporate performance of a sample of 208 Vietnamese motorcycle corporations. The study concluded that there is a positive relationship between green products and corporate performance represented by market position, cost reduction, profits, and reputation. Additionally, Fraj et al. [39] confirmed that a proactive environmental strategy and innovation favour organisational competitiveness.

Although previous studies came out with similar findings indicating that green practices could improve competitiveness, some argue that engaging in such practices might impose costs and consequently negatively affect the corporation. Sarkis and Cordeiro [85] investigated the relationships between short-run financial performance represented by return on sales and pollution prevention and the end-of-pipe policies within 482 US firms in 1992. The study found that the end-of-pipe and pollution prevention policies have a negative relationship with financial performance and that pollution prevention had a larger negative relationship with return on sales than did end-of-pipe policy.

Interestingly, González-Benito and González-Benito [41] found that products- and processes-focused practices had different impacts on different dimensions of corporate performance. While the study found that product design practices had a significant relationship with the market performance (reputation, image, market expectations, and new products), such a relationship seemed to be insignificant with regard to the relationship between processes-focused practices and market performance. However, the study found that both practices do not have significant relationships with other performance measures (e.g. quality, cost, financial performance). Such inconclusiveness in the results of previous studies creates fertile ground for further investigation.

Many regard corporate social/environmental concepts as a Western phenomenon that results from developed institutions and robust systems many of which are hard to find in developing countries [4, 64]. Such an understanding would have guided studies to focus on corporate social/environmental concepts and their relationship with the health of an organisation exclusively in developed countries. This disproportionate focus on developing nations means that the same relationship in developing countries has been overlooked. This imbalance is evident in Orlitzky et al. [68] and Horváthová [50]. Interestingly, such studies noted that the country location or/and regulations influence how environmental issues relate to corporate performance [50]. Given this background, our research enriches our understanding of the relationship between corporate social/environmental concepts and organisation in Libya as a developing country.

Moreover, an overview of previous literature has revealed a dearth in research on the subject in developing countries, and specifically in Arab countries such as Libya. For instance, Etzion [36] stated that very few studies have, until recently, considered how corporate performance requires the consideration of environmental issues in the context of non-developed countries. This oversight necessitates empirical research detailing the relationship between sustainable corporate performance and firm performance for the context of developing countries [42].

\section{Resource-based view theory}

The resource-based view (RBV) theory has been extensively applied in the aim of investigating the relationships between the resources and competitiveness. RBV theory relies on the assumption that performances of companies are varied due to resources heterogeneity across the corporations $[15,16,48,51,97,98,101]$. An organisation's resources constitute its dynamic capabilities and its ability to create, extend, or modify its resources [ [9], p. 3]. It includes routines that determine an organisation's accomplish its goals. This depends heavily on tacit knowledge [22, 37, 56, 99].

The resource-based view theory often overlooks and under-appreciates the importance of the natural environment [48]. Hart [48] summarised several capabilities that can be possible sources of competitiveness, namely technology, design, production, procurement, distribution, and services. Consequently, the study assumes that green technology practices could be considered environmental capabilities that capitalise on tacit knowledge that is difficult to observe or replicate $[22,55]$. Organisations can boost their competitiveness by capitalising on this often overlooked resource [22, 48, 55, 78, 13]. Accordingly, the resource-based method promotes the efficient use of resources for improved environmental sustainability and greater competitiveness [65]. 
Notwithstanding the importance of RBV, the theory was criticised for its focus on overall performance instead of focusing on the different outputs. For instance, Ray et al. [79] suggested with the disaggregated dependent variable when testing the RBV. Moreover, there is evidence of the lack of environmental management studies in developing countries [4, 36, 42, 64]. For instance, Etzion [36] has stated that only a few studies have investigated the link between green practices and corporations' performances. Therefore, further empirical research is required in developing countries [42]. As a response to such calls, the current study aims to determine the influences of green technology practices and competitive aspects of industrial corporations. Consequently, it aims to answer the following question:

\section{To which extent can the green technology explain the} competitiveness?

Extensive literature review and in line with RBV theory, the following hypotheses are developed:

$H$ Green technology aspects contribute positively to the different aspects of competitiveness.

HI.1 Products-focused practices contribute positively to the image aspects of competitiveness.

HI.2 Products-focused practices contribute positively to the profit aspects of competitiveness.

HI.3 Products-focused practices contribute positively to the satisfaction aspects of competitiveness.

H2.1 Processes-focused practices contribute positively to the image aspects of competitiveness.

H2.2 Processes-focused practices contribute positively to the profit aspects of competitiveness.

H2.3 Processes-focused practices contribute positively to the satisfaction aspects of competitiveness.

\section{The questionnaire development}

The items of the questionnaire have been selected from previous environmental management literature to measure the variables as follows: 13 items have been used to represent conventional green practices (e.g. [20, 28, 41, $58,76,87,88])$ and 11 items have been used for the competitiveness (e.g. [8, 28, 31, 54, 61, 76, 87, 88, 93, 94]).

All questionnaire-based surveys require testing for reliability and validity before conducting the actual survey. Content validity means ensuring the scale can measure what it is supposed to measure [46]. In other words, the data are considered to be contently validated if experts agree that the instruments of the study include items that can cover all variables [14, 47, 83]. Additionally, Hair et al. [46] noted that validation refers to referring specialists or experts to review the suitability of the items within the construct. Validity means that the indicators represent the concept accurately while reliability pertains to the consistency between the indicators [46]. When a questionnaire is valid and reliable, it means that its question is understood clearly by the respondents, and the response options are appropriate [96].

All items were subjected to reliability and validity test prior to the main data collection. With regard to the content validity of the questionnaire, experts in the same field have checked the questions in the instrument to ensure that they are comprehensive, are relevant, and reflect the phenomena to be measured. Additionally, the researcher conducted two interviews with those in charge of environmental activities in two corporations with characteristics similar to the target population. The respondents' feedback suggested that the questionnaire is understandable and did not need much time to be completed. The experts equally indicated that since the respondents are familiar with environmental issues, they are likely to be comfortable with the proposed seven-point Likert scale.

Additionally, a sample of 50 environmental managers were randomly choosing to answer the questionnaire for the pilot test. Several studies have recommended that a sample size of 50 could be an adequate for factor analysis $[30,40,89]$ and reliability tests $[47,49,84]$.

First, we validated the factor structure using exploratory factor analysis. This method is commonly used in environmental literature. For instance, Mardani et al. [65] researched several prominent databases to determine the frequency of SEM techniques used in studies in the period from 2005 to 2016. Interestingly, they found that around $61 \%$ of the published papers have used exploratory factor analysis to validate their data. The items of competitiveness are loaded on three dimensions named image-, satisfaction-, and profits-related aspects with total variance explained value of 55.286. Additionally, the items of green practices variable are loaded on two factors named processes-focused and products-focused explaining the total variance of 62.458.

Second, the reliability test was conducted to insure the existence of the consistency between the indicators [46]. A Cronbach's alpha range $<0.6$ is poor, moderate between 6 and 7, good when ranging between 7 and 8, very good between 8 and 9, and excellent when equal to greater than $9[46,67]$. If alpha $>0.95$, the items should be checked to ensure that they measure different aspects of the concept [46]. Reliability test resulted in Cronbach's alpha's values 
greater than 0.6, which is considered acceptable as mentioned by Nunnally et al. [67] and Hair et al. [46]. Table 1 shows a summary of factor analysis and reliability.

\section{Analysing the main data}

After the confirmation of both validity and reliability of the instrument, the actual survey is carried out. The data were collected from a sample of 224 Libyan industrial corporations that represent a response rate of $82 \%$. The target of the study was organisational level as represented by either production manager, environmental management manager, or general manager in small companies [95]. The following section presents the descriptive statistics of the questionnaire items.

First, Green practices are the activities undertaken by the corporations to make environmental sound regarding their products and manufacturing processes. In general, this variable scored a mean value of 4.14 for all items with a standard deviation of 1.47338 . The previous scores indicate that the corporations give moderate importance to these practices.

The mean values of the items ranged from 3.91 to 4.38 . The highest value was for preferring green products in purchasing, while the lowest value was for consolidating the shipments. The remaining items were located between these two values as follows: recyclable packaging with a mean value of 3.93 , followed by product's ability to dismantle with a mean value of 3.98 , adopting recycling systems with a mean value of 4.07 , cleaner transportation methods with a mean value of 4.13 , each of reducing resource consumption during the production and product usage stages scored a mean value of 4.18 , ecological material in primary packaging with a mean value of 4.19 , and finally each of clean processes and technologies and substituting polluting material scored a mean value of 4.32 , and finally reducing waste generation during production scored a mean value of 4.34. Table 2 summarises the descriptive statistics of green practices.

Second, competitiveness reflects the degree to which environmental management was beneficial for a number of corporate goals. Items related to the competitiveness have mean values that ranged from 4.10 to 4.92 , which indicate that some improvements were gained as results of engaging in environmental activities, especially in aspects related to employees' retention, sales, and management satisfaction.

Table 1 Reliability and factor analysis results

\begin{tabular}{llllll}
\hline & \multicolumn{2}{l}{ Green practices } & & \multicolumn{2}{l}{ Competitiveness } \\
\cline { 2 - 3 } & $\begin{array}{l}\text { Green processes-focused } \\
\text { practices }\end{array}$ & $\begin{array}{l}\text { Green products-focused } \\
\text { practices }\end{array}$ & Satisfaction & Image & Profits \\
\hline Cronbach's alpha & 0.863 & 0.863 & 0.714 & 0.686 \\
Total variance explained & 62.458 & & 55.286 & \\
\hline
\end{tabular}

Table 2 Descriptive statistics of green practices

\begin{tabular}{|c|c|c|c|c|c|}
\hline & \multicolumn{5}{|l|}{ Descriptive statistics } \\
\hline & & $N$ & Minimum & Maximum & Mean \\
\hline Q1 & Clean processes and technologies & 226 & 1 & 7 & 4.32 \\
\hline Q2 & Substituting polluting material & 226 & 1 & 7 & 4.32 \\
\hline Q3 & Cleaner transportation methods & 226 & 1 & 7 & 4.13 \\
\hline Q4 & Recyclable packaging & 226 & 1 & 7 & 3.93 \\
\hline Q5 & Ecological material in primary packaging & 226 & 1 & 7 & 4.19 \\
\hline Q6 & Preferring green products in purchasing & 226 & 1 & 7 & 4.38 \\
\hline Q7 & Adopting recycling systems & 226 & 1 & 7 & 4.07 \\
\hline Q8 & Consolidating the shipments & 226 & 1 & 7 & 3.91 \\
\hline Q9 & Reducing waste generation during production & 226 & 1 & 7 & 4.34 \\
\hline Q10 & Reducing waste generation at the product usage stage & 226 & 1 & 7 & 3.93 \\
\hline Q11 & Reducing resource consumption at the product usage & 226 & 1 & 7 & 4.18 \\
\hline Q12 & Product's ability to dismantle & 226 & 1 & 7 & 3.98 \\
\hline Q13 & Reducing resource consumption during the production & 226 & 1 & 7 & 4.18 \\
\hline Mean & & 4.14 & & & \\
\hline
\end{tabular}


Table 3 Descriptive statistics of competitiveness

\begin{tabular}{|c|c|c|c|c|c|}
\hline & \multicolumn{5}{|l|}{ Descriptive statistics } \\
\hline & & $N$ & Minimum & Maximum & Mean \\
\hline Q1 & Achieving higher long-term profits & 226 & 1 & 7 & 4.72 \\
\hline Q2 & Improving product image & 226 & 1 & 7 & 4.10 \\
\hline Q3 & Increasing management satisfaction & 226 & 1 & 7 & 4.61 \\
\hline Q4 & Increasing shareholder satisfaction & 226 & 1 & 7 & 4.57 \\
\hline Q5 & Increasing sales & 226 & 1 & 7 & 4.67 \\
\hline Q6 & Improving corporate image & 226 & 1 & 7 & 4.53 \\
\hline Q7 & Productivity & 226 & 1 & 7 & 4.59 \\
\hline Q8 & Increasing market share & 226 & 1 & 7 & 4.58 \\
\hline Q9 & Better recruitment and staff retention & 226 & 1 & 7 & 4.92 \\
\hline Q10 & Achieving higher short-term profits & 226 & 1 & 7 & 4.57 \\
\hline Q11 & Reducing cost & 226 & 1 & 7 & 4.58 \\
\hline The Mean & & 4.58 & & & \\
\hline
\end{tabular}

Table 3 shows that better recruitment and staff retention recorded the highest mean value of 4.92, followed by achieving higher long-term profits with a mean value of 4.72 , increasing sales with a mean value of 4.67 , and increasing management satisfaction with a mean value of 4.61 , followed by productivity with a mean value of 4.59 ; both reducing cost and increasing market share have the same mean value of 4.58 , followed by each of achieving higher short-term profits and increasing shareholders satisfaction with a mean value of 4.57 , improving corporate image with a mean value of 4.53 , and finally improving product image with a mean value of 4.10 .

In addition to the descriptive part, data were screened for problems in the data that might undermine its validity.

We performed an independent-sample $T$ test to identify the differences between the early and late respondents $[10,17,46]$. The test revealed no significant difference between the two groups. Also, there were no outliers in the data after using Mahalanobis distance, which represent the distance from the case to the centroid of all cases for predictor variables [47, 91]. The Harman single factor was also used to identify serious threats in the data due to common method variance $[45,69,70]$. Interestingly, the single-factor model resulted in more than one factor, and the first factor explained 30.497 of the variance, which indicates that common method bias was not a serious threat in this study.

Additionally, correlation matrix shows that there is no evidence of existence of multicollinearity between the variables as all correlation values are less than 0.8 according to the rule of thumb by Hair et al. [46], who stated that when the correlation between two independent variables is higher than 0.8 , it can be an indicator of the existence of multicollinearity, which can deteriorate the results of the analysis. Table 4 shows the correlation results.

\section{Structure equation modelling technique}

Structural equation modelling is when multiple variables are studied using statistical methods to determine how they relate to each other [47]. This technique enables software such as AMOS to be utilised for assessing the confirmatory factor analysis and building the measurement model that is currently allocated before evaluating the structural model (the proposed theoretical

Table 4 Correlation analysis results

\begin{tabular}{llll}
\hline & Green practices & & Competitiveness \\
\cline { 2 - 3 } $\begin{array}{llll}\text { Green processes-focused } \\
\text { practices }\end{array}$ & $\begin{array}{l}\text { Green products-focused } \\
\text { practices }\end{array}$ & Satisfaction Profits \\
\hline Green process & 1 & 1 & 1 \\
Green products & $0.628^{* *}$ & $0.176^{* *}$ & $0.454^{* *}$ \\
Satisfaction & $0.184^{* *}$ & $0.317^{* *}$ & $0.459^{* *}$ \\
Image & $0.282^{* *}$ & $0.206^{* *}$ & 1 \\
Profits & $0.203^{* *}$ & $0.452^{* *}$ \\
\hline
\end{tabular}


framework), which will help in validating the hypothesised model [19, 45].

The framework of this research was developed from a review of the literature from which we derived the concepts that framed the research and the analytical tools to process the data, particularly structural equation modelling (SEM) using AMOS. We adopt a reflective model given that our indicators are interchangeable and measure common themes [53, 77]. Interchangeable indicators help measure the construct based on several relevant items underlying the domain of the construct [25, 66]. It also means that adding or deleting an item will not affect the conceptual domain of the construct [53, 77]. This approach is justified as several studies have used it to measure models that comprise few items.

\section{Confirmatory factor analysis (CFA)}

CFA was applied for both endogenous and exogenous variables using structural equation modelling (SEM) AMOS 20 technique. The following section discusses the results of confirmatory factor analysis.

First, for the exogenous variables (green practices) Fig. 1 shows that eight items were subject to CFA. It also shows that the $P$ value is significant, which indicates the lack of fit in the exogenous variables. Therefore, Q10 is deleted as it represents the highest modification index item.

After deleting Q10, the fit is improved and constructs left with seven items (four items from processes-focused practices and three items from products-focused practices). Figure 2 shows the results of CFA for exogenous variables. It shows that after deleting Q10, all criteria are improved ( $P$, Chi-square/ $d f$, GFI, TLI, CFI, and RMSEA).

Second, for the endogenous variables (competitiveness aspects) Fig. 3 shows that 11 items were subject to CFA.
It also shows that $P$ value is significant, which indicates the lack of fit in the endogenous variables. Therefore, Q7 was deleted as it represents the highest modification index items.

After deleting Q7, the fit is improved and constructs left with ten items (four items from profits-related aspects, three items from image-related aspects, and three items for satisfaction-related aspects). Figure 4 shows the results of CFA for endogenous variables. It shows that after deleting Q7, all criteria improved ( $P$, Chi-square/df, GFI, TLI, CFI, and RMSEA).

\section{The structural model of the study}

After conducting the confirmatory factor analysis for both the exogenous and endogenous variables, the study reached the final structural model as shown in Fig. 5. The figure shows that five constructs left with 17 items after deleting questions based on their factor loadings and higher modification indexes. Seven items resulted from CFA as probable measurements of green practices within the Libyan industrial sectors and ten items reflect the constructs of the competitiveness. Figure 5 illustrates the final structural model that resulted from AMOS 20.

The loadings of items range from the lowest 0.47 of profit question 10 to the highest 0.79 of question 3 of the processes-focused practices construct, which reflects that the factor loading of each item is higher than the suggested 0.40 cut-off criteria for SEM loadings [47].

The reliability test of both environmental technology and competitiveness constructs recorded Cronbach's alpha values greater than 0.6 for each factor. This is an acceptable range according to Nunnally et al. [67] and Hair et al. [46]. Furthermore, correlation matrix recorded no evidence of multicollinearity between

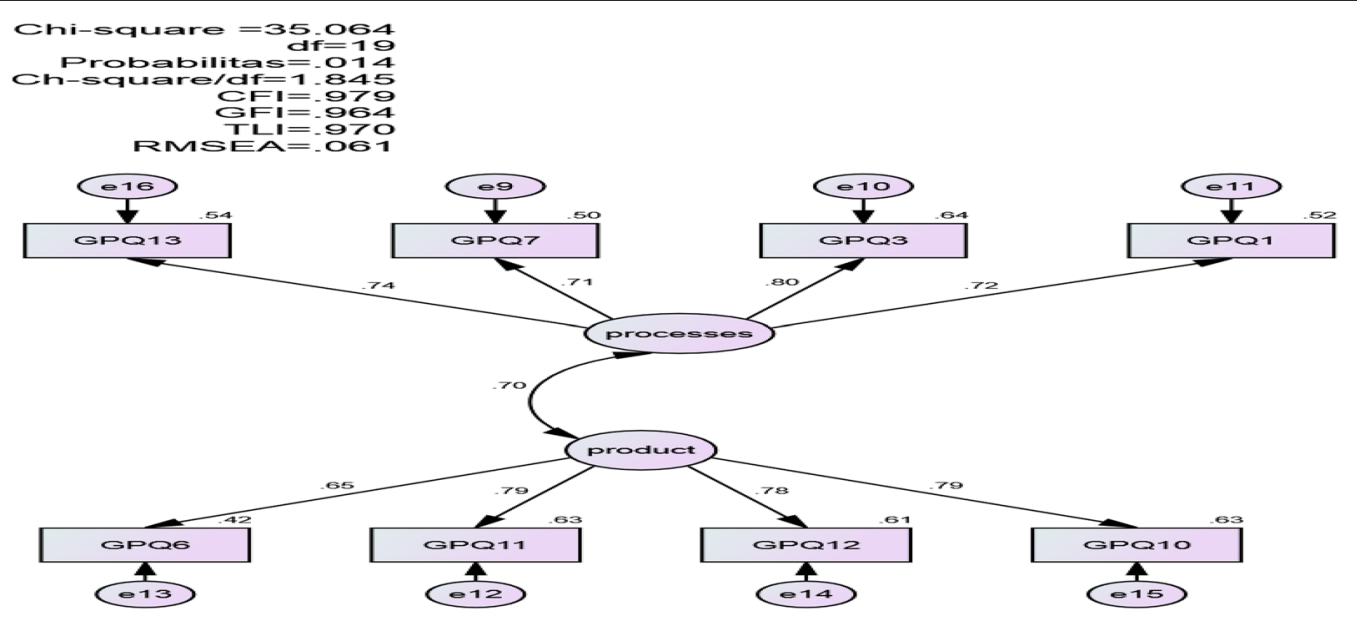

Fig. 1 The hypothesised model of green practices 

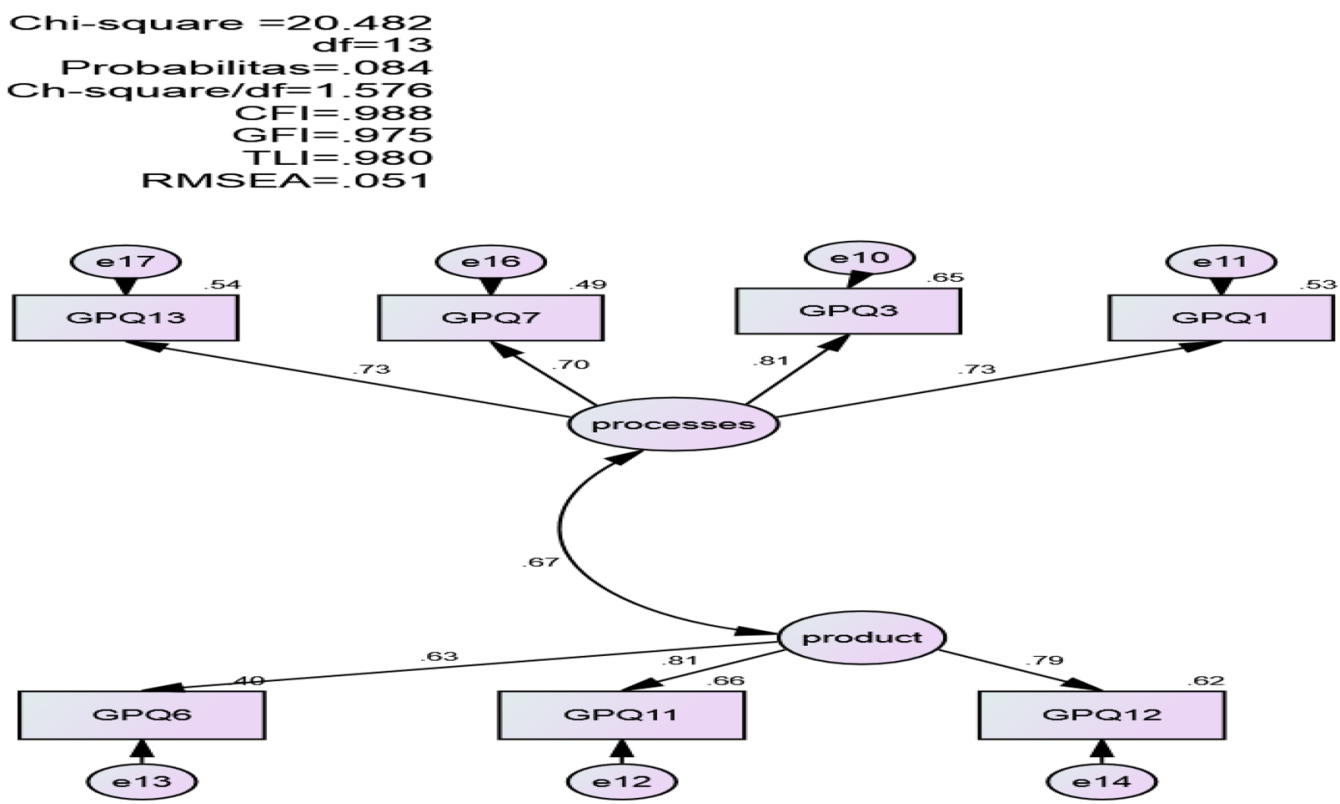

Fig. 2 CFA of green practices

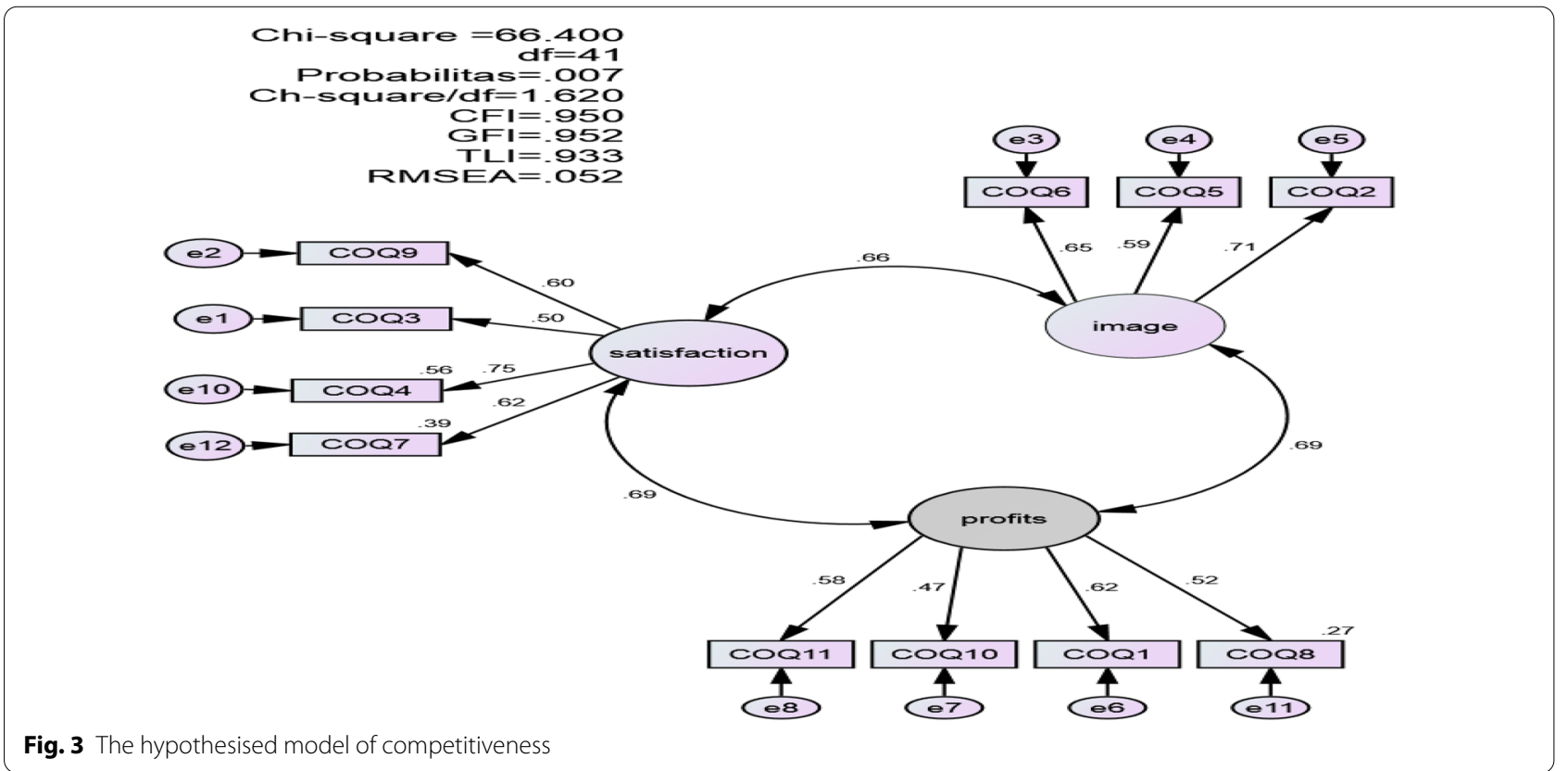

the variables as all correlation values are less than 0.8 . According to Hair et al. [46], if the correlation $>0.8$, then severe multicollinearity may be present. Table 5 shows the loading of items, correlations, and reliability of the structural model.

These results show that the model is statistically accepted [18, 45, 47]. Additionally, other criteria such as CFI, GFI, TLI, and RMSEA support that the model fits the data very well.

Hair et al. [47] recommended less than three indicators per construct. Chin [23] found that structure equation modelling should include a maximum of four items per construct in for acceptable results. More than that, 
Fig. 4 CFA of competitiveness
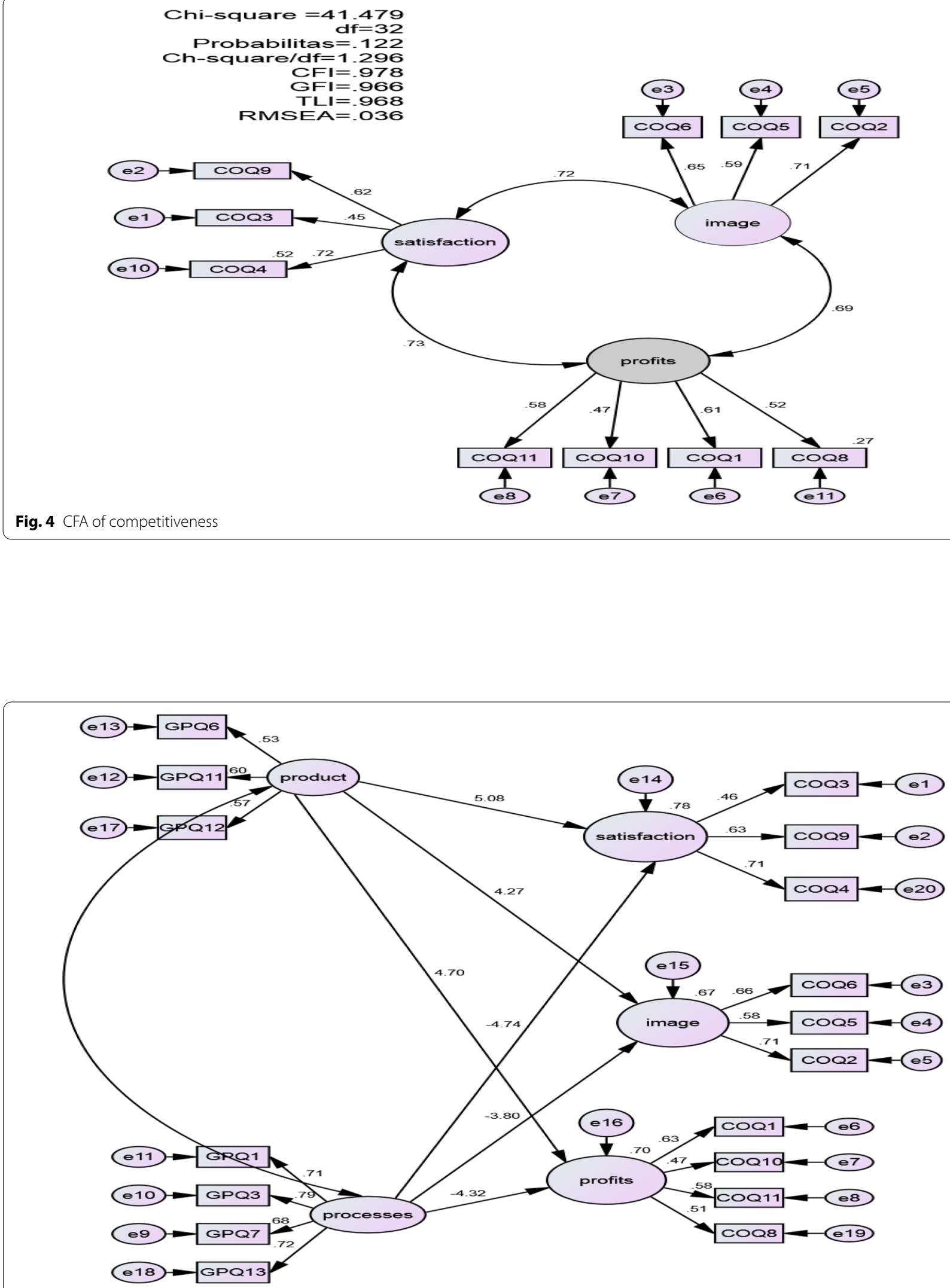

Fig. 5 The structural model 
Table 5 The loading of items, correlations, and reliability of structural model

\begin{tabular}{|c|c|c|c|c|c|c|c|}
\hline \multirow[t]{2}{*}{ Factors } & \multirow[t]{2}{*}{ Codes } & \multicolumn{5}{|c|}{ Items' loading } & \multirow[t]{2}{*}{ Reliability } \\
\hline & & $\begin{array}{l}\text { Processes- } \\
\text { focused } \\
\text { practices }\end{array}$ & $\begin{array}{l}\text { Products- } \\
\text { focused } \\
\text { practices }\end{array}$ & Satisfaction & Profits & Image & \\
\hline \multirow[t]{3}{*}{ Processes-focused practices } & GPQ1 & 0.71 & & & & & 0.83 \\
\hline & GPQ3 & 0.79 & & & & & \\
\hline & $\begin{array}{l}\text { GPQ7 } \\
\text { GPQ13 }\end{array}$ & $\begin{array}{l}0.68 \\
0.72\end{array}$ & & & & & \\
\hline \multirow[t]{3}{*}{ Products-focused practices } & GPQ6 & & 0.53 & & & & 0.75 \\
\hline & GPQ11 & $0.537^{* *}$ & 0.60 & & & & \\
\hline & GPQ12 & & 0.57 & & & & \\
\hline \multirow[t]{3}{*}{ Satisfaction } & $\mathrm{COQ} 3$ & & & 0.46 & & & 0.61 \\
\hline & COQ9 & $0.190^{* *}$ & $0.214^{* *}$ & 0.63 & & & \\
\hline & COQ4 & & & 0.71 & & & \\
\hline \multirow[t]{3}{*}{ Profits } & COQ1 & & & & 0.63 & & 0.60 \\
\hline & COQ10 & $0.197^{* *}$ & $0.237^{* *}$ & $0.474^{* *}$ & 0.47 & & \\
\hline & $\begin{array}{l}\text { COQ11 } \\
\text { COQ8 }\end{array}$ & & & & $\begin{array}{l}0.58 \\
0.51\end{array}$ & & \\
\hline \multirow[t]{3}{*}{ Image } & COQ6 & & & & & 0.66 & 0.69 \\
\hline & COQ5 & $0.314^{* *}$ & $0.258^{* *}$ & $0.473^{* *}$ & $0.452^{* *}$ & 0.58 & \\
\hline & COQ2 & & & & & 0.71 & \\
\hline
\end{tabular}

${ }^{* *}$ Correlation is significant at the 0.01 level (two tailed)

risks produce unacceptable results. With this, we can conclude that the model of this research is acceptable.

\section{Results}

The regression weights table (Table 6) shows that products-focused practices positively influence the three aspects of competitiveness, which reflects the support of the first three hypotheses (H1.1, H1.2, and H1.3). On the other hand, the table shows that there is not enough evidence to support significant relationships between the processes-focused green practices and the aspects of competitiveness $(P>0.05$ for all processes-related aspects constructs). Therefore, the last three hypotheses were rejected (H2.1, H2.2, and H2.3). Moreover, it shows that the expected relationships seem to be negative.
The result shows that products-focused practices influence all aspects of organisational competitiveness. Such a result is consistent with previous literature. For instance, Chuang and Huang [26] found that the competitiveness of Taiwan manufacturing companies was enhanced by incorporating environmental practices. Famiyeh et al. [38] reached the same conclusion. Additionally, environmental innovation has a positive impact on the competitiveness of Chinese manufacturing enterprises [27]. Moreover, Lee et al. [59] found that the competitive advantages of Italian manufacturing SMEs was positively affected by the dimensions of sustainability including the environmental once. Ashton et al. [11] concluded that clean development mechanisms affect the performance of Malaysian companies positively. Moreover, Junquera and Barba-Sánchez [52] revealed that Spanish companies

Table 6 Regression weights: (group number 1-default model)

\begin{tabular}{|c|c|c|c|c|c|c|}
\hline & & & Estimate & S.E. & C.R. & $P$ \\
\hline Satisfaction & $\leftarrow$ & Product & 3.377 & 1.699 & 1.987 & 0.047 \\
\hline Image & $\leftarrow$ & Product & 4.271 & 2.068 & 2.066 & 0.039 \\
\hline Profits & $\leftarrow$ & Product & 4.300 & 2.097 & 2.050 & 0.040 \\
\hline Profits & $\leftarrow$ & Processes & -3.478 & 1.849 & -1.881 & 0.060 \\
\hline Satisfaction & $\leftarrow$ & Processes & -2.771 & 1.493 & -1.856 & 0.063 \\
\hline Image & $\leftarrow$ & Processes & -3.342 & 1.821 & -1.835 & 0.066 \\
\hline
\end{tabular}


experienced cost-based and differentiation-based competitive advantages when they adopted a proactive environmental policy.

On the other hand, processes-focused practices do not have any significant effects on the dimensions of competitiveness. The results indicate any improvements in the processes-focused practices will not lead to any improvements in the competitiveness-related aspects. This result leads to rejecting the last three hypotheses $(\mathrm{H} 2.1, \mathrm{H} 2.2$, and H2.3). These results are consistent with the findings of other studies. For instance, Aboelmaged [1] found that when Egyptian SMEs integrated technology and environmental regulations, they did not see significant improvements in sustainable manufacturing practices. Additionally, González-Benito and González-Benito [41] concluded that processes-focused practices do not have significant relationships with performance measures such as quality, cost, financial, and market performance.

According to Poole and Van de Ven [74], in the case of failed hypotheses, it could be due to temporal differences. For instance, new organisations behave differently to seasoned and established organisations. This reasoning applies to this study as the majority of environmentally related studies focused on established organisations in developed countries which behave differently to organisations in developing countries that do not have the same regulatory framework and corporate environment as those found in developed nations. As seen in this research, this is true for the case of Libya. In summary, the different stages of development could explain why the results of this study differ from those of the majority of the literature.

\section{Conclusion}

Exploratory and confirmatory factor analyses were applied to confirm each construct of the model. Doing so resulted in two constructs representing green technology, namely processes- and products-focused practices. Additionally, competitiveness was laid on profits-, satisfaction-, and image-related practices. The study expected that each construct of competitiveness would be explained by each of the green processes- and products-focused practices. This was in line with RBV theory, which assumes that engaging in environmental practices will improve the competitive position of the company [48], and that only proactive environmental governance is a source of competitiveness, because it was unique to the firm and difficult to obtain by competitors [43]. However, the results show that only products-focused practices could improve the three dimensions of competitiveness. Additionally, it revealed that processes-focused practices do not contribute to any of the competitiveness aspects. Such results are in line with previous literature $[41,85]$.
It corresponds with the assumption that the profits of the company might be affected by type of environmental innovation rather than the environmental innovation in general [81]. It also could be due to that products are something that can be seen and evaluated by the customers compared to the processes, which reflect internal intangible resources that cannot be evaluated directly by the customers. Therefore, the consequences of such processes are not valuable unless transformed into tangible outputs. These outputs are represented by products.

The paper contributes to the body of knowledge by stating and testing the potential relationships between each practice of green technology and a multidimensional approach to competitiveness. It contributes to the debate of whether it pays to be green. Additionally, it highlighted the lack of research on environmental issues in developing countries [36, 42]. It articulated the competitiveness of Libyan industrial companies as weak $[2,3$, $5-7,75]$, and such weakness could be attributed to environmental issues $[34,71]$. Therefore, it may help to create or improve the awareness of the decision-makers in Libyan industrial corporations towards their environmental actions, and ways to utilise such actions in improving both the surrounding environment and the corporations' goals.

Despite the contributions of the paper, it has several limitations that should be taken into consideration when referring to this paper. First, the study used a selfreported questionnaire filled in by managers in the study sample. Therefore, survey data might be subject to social desirability bias [12, [86]]. Second, this study was conducted in Libya, which is considered a developing country, caution should be taken when generalising the results of the study, and the results may be generalised only to a similar environment and stage of development. Third, another limitation of the study is that some items have been deleted from the hypothesised models during the process of CFA, which may affect the validity of the construct. However, reflective models are not disturbed the addition or deletion of an item as it preserves the conceptual integrity of the construct [53, 77]. Finally, although 224 industrial corporations can represent an acceptable sample size for this type of study, future studies should increase the sample size to obtain stronger results. This is based on the fact that the sample size can affect the results of a study, and the bigger sample size, the more likely the results are credible and generalisable [47].

\section{Abbreviations}

RBV: Resource-based view theory; AMOS: Analysis of moment structures; SEM: Structural equation modelling; CFA: Confirmatory factor analysis; GFI: Goodness-of-fit index; TLI: Tucker-Lewis index; CFI: Comparative fit index; RMSEA: Root mean square error of approximation. 


\section{Authors' contributions}

All the mentioned authors have substantial contributions to the conception of the manuscript, analysis, or interpretation of data for the manuscript. MAS is the corresponding author, and he has built the framework of the study and analysed the main data. FS has major contributions to the study, and the co-author has substantial contribution in screening the data and conducting the pilot study'test. $\mathrm{HBIH}$ has a great contribution in reviewing the data analysis section, and his comments and recommendations have improved the data analysis process and facilitated the interpretation of the data. MFS is the author who summarised the outputs of literature review and reviewed the whole manuscript. All authors have read and approved the manuscript.

\section{Acknowledgements}

We wish to dedicate our acknowledgements and appreciations to all participants in our survey at the industrial companies. Without their cooperation and valuable feedback, it was impossible to complete the study. Additionally, we would like to present our special thanks to the staff at University Utara Malaysia and University Kuala Lumpur for their support.

\section{Competing interests}

The authors declare that there are no significant competing financial, professional or personal interests that may affect the manuscript.

\section{Availability of data and materials}

The data that support the findings of this study are available from the corresponding author [Milad Abdelnabi Salem] on request.

\section{Funding}

No specific funding has been provided for the research.

\section{Author details}

${ }^{1}$ Community College of Qatar, Doha, Qatar. ${ }^{2}$ Business School, Taylor's University, Kuala Lumpur, Malaysia. ${ }^{3}$ Business School, University Kuala Lumpur, 74, Jalan Raja Muda Abdul Aziz, Kampung Baru, 50300 Kuala Lumpur, Malaysia.

\section{Received: 4 October 2019 Accepted: 25 February 2020} Published: 2 April 2020

\section{References}

1. Aboelmaged M (2018) The drivers of sustainable manufacturing practices in Egyptian SMEs and their impact on competitive capabilities: a PLS-SEM model. J Clean Prod 175:207-221

2. Aboujdiryha AA (2011) Privatisation processes and firm performance: the Libyan industrial sector. Unpublished PhD thesis, University of Twente, Netherlands

3. Ahmed AS (2010) An empirical analysis of Libyan business environment and foreign direct investment. Unpublished PhD thesis, Durham University

4. Ahmad NM, Mousa FR (2010) Corporate environmental disclosure in Libya: a little improvement. World J Entrep Manag Sustain Dev 6(12):149-159

5. Alghadafi EM, Latif M (2010) Simulation of a Libyan cement factory. In: Proceedings of the world congress on engineering, WCE 2010, vol III, London

6. Ali I, Harvie C (2011) Oil related shocks and macroeconomic adjustment: case of Libya, 1970-2007. Paper presented at the 40th Australian Conference of Economists, Canberra Australia

7. Almahdi IA (2011) The mediating effect of competitive advantage and environment on the relationship of innovation practices and technology adoption on SME performance. Unpublished PhD thesis, University Utara Malaysia

8. Al-Sharairi JA, Al-Awawdeh WM (2012) The relationship between target costing and competitive advantage of Jordanian private universities. Int J Bus Manag 7(8):123-142

9. Ambrosini V Bowman C (2009) What are dynamic capabilities and are they a useful construct in strategic management? Int J Manag Rev 11(1):29-49
10. Armstrong JS, Overton TS (1977) Estimating nonresponse bias in mail surveys. J Mark Res 14(3):396-402

11. Ashton W, Russell S, Futch E (2017) The adoption of green business practices among small US Midwestern manufacturing enterprises. J Environ Plan Manag 60(12):2133-2149

12. Baba H (2004) Corporate social responsibility and environmental performance of small-medium enterprises. Unpublished PhD thesis, University Utara Malaysia

13. Barney J, Wright M, Ketchen DJ Jr (2001) The resource-based view of the firm: Ten years after 1991. J manag 27(6):625-641

14. Bhattacherjee A (2012) Social Science Research: Principles, Methods, and Practices, 2nd edn. The University of South Florida, Tampa, Florida, USA

15. Barney J (1991) Firm resources and sustained competitive advantage. J Manag 17(1):99-120

16. Barney JB (1995) Looking inside for competitive advantage. Acad Manag Exec 9(4):49-61

17. Bluman A (2011) E-study guide for elementary statistics: a step by step approach. Cram101 Textbook Reviews

18. Byrne BM (2010) Structural equation modelling with AMOS: basic concepts, application and programming, 2nd edn. Routledge, New York

19. Byrne BM (2016) Structural equation modelling with AMOS: basic concepts, applications, and programming. Routledge, New York

20. Boiral O, Henri J (2012) Modelling the impact of ISO 14001 on environmental performance: a comparative approach. J Environ Manag 99(2012):84-97

21. Buysse K, Verbeke A (2003) Proactive environmental strategies: a stakeholder management perspective. Strateg Manag J 24(5):453-470

22. Berchicci L, Dowell G, King AA (2012) Environmental capabilities and corporate strategy: exploring acquisitions among US manufacturing firms. Strateg Manag J 33(9):1053-1071

23. Chin WW (1998) Commentary: Issues and opinion on structural equation modeling. MIS Quarterly. 22(1):vii-xvi

24. Christmann P (2000) Effects of "best practices" of environmental management on cost advantage: the role of complementary assets. Acad Manag J 43(4):663-680

25. Churchill GA Jr (1979) A paradigm for developing better measures of marketing constructs. J Mark Res 16(1):64-73

26. Chuang SP, Huang SJ (2018) The effect of environmental corporate social responsibility on environmental performance and business competitiveness: the mediation of green information technology capital. J Bus Ethics 150(4):991-1009

27. Cao Y, You J (2017) The contribution of environmental regulation to technological innovation and quality competitiveness: an empirical study based on Chinese manufacturing enterprises. Chin Manag Stud 11(1):51-71

28. Chiou TY, Chan HK, Lettice F, Chung SH (2011) The influence of greening the suppliers and green innovation on environmental performance and competitive advantage in Taiwan. Transp Res Part E Logist Transp Rev 47(6):822-836

29. Clark V, Creswell J (2010) Designing and conducting mixed methods research. Sage Publications Inc, Thousand Oaks

30. de Winter JCF, Dodou D, Wieringa PA (2009) Exploratory factor analysis with small sample sizes. Multivar Behav Res 44(2):147-181

31. Del Brío JÁ, Fernández E, Junquera B (2007) Management and employee involvement in achieving an environmental action-based competitive advantage: an empirical study. Int J Hum Resour Manag 18(4):491-522

32. Diana GC, Jabbour CJC, de Sousa Jabbour ABL, Kannan D (2017) Putting environmental technologies into the mainstream: Adoption of environmental technologies by medium-sized manufacturing firms in Brazil. J cleaner prod 142:4011-4018

33. Duncan WJ, Ginter PM, Swayne LE (1998) Competitive advantage and internal organizational assessment. Acad Manag Exec 1993-2005:6-16

34. Eltaief AA, Kamaruddin BH, Mohamad S, Abessi M (2009) Cost efficiency of construction firms in Libya using the data envelopment analysis method. Int J Glob Bus 2(2):154-179

35. Eltayeb TK, Zailani S, Ramayah T (2011) Green supply chain initiatives among certified companies in Malaysia and environmental sustainability: investigating the outcomes. Resour Conserv Recycl 55(5):495-506 
36. Etzion D (2007) Research on organizations and the natural environment, 1992-present: a review. J Manag 33(4):637-664

37. Freeman J, Hannan MT (1989) Setting the record straight on organizational ecology: Rebuttal to Young. Am J Sociol 95:425-439

38. Famiyeh S, Kwarteng A, Asante-Darko D, Dadzie SA (2018) Green supply chain management initiatives and operational competitive performance. Benchmarking Int J 25(2):607-631

39. Fraj E, Matute J, Melero I (2015) Environmental strategies and organizational competitiveness in the hotel industry: the role of learning and innovation as determinants of environmental success. Tour Manag 46:30-42

40. Gorsuch RL (1974) Factor analysis. Saunders, Philadelphia

41. González-Benito J, González-Benito Ó (2005) Environmental proactivity and business performance: an empirical analysis. Omega 33(1):1-15

42. Goyal P, Rahman Z, Kazmi A (2013) Corporate sustainability performance and firm performance research: literature review and future research agenda. Manag Decis 51(2):361-379

43. Guenster N, Bauer R, Derwall J, Koedijk K (2011) The economic value of corporate eco-efficiency. Eur Financ Manag 17(4):679-704

44. Hussain HI, Salem MA, Rashid AZA, Kamarudin F (2019) Environmental impact of sectoral energy consumption on economic growth in Malaysia: evidence from ARDL bound testing approach. Ekoloji Dergisi 28(107):199-210

45. Hair JF Jr, Black WC, Babin BJ, Andersen RE, Tatham RL (2006) Multivariate data analysis, 6th edn. Pearson Prentice Hall, Upper Saddle River

46. Hair JF, Money AH, Samouel P, Page M (2007) Research methods for business. Wiley, West Sussex

47. Hair JF Jr, Black WC, Babin BJ, Andersen RE, Tatham RL (2010) Multivariate data analysis, 7th edn. Pearson Prentice Hall, Upper Saddle River

48. Hart S (1995) A natural-resource-based view of the firm. Acad Manag Rev 20(4):986-1014

49. Hopkins WG (2000) Measures of reliability in sports medicine and science. Sports Med 30(1):1-15

50. Horváthová E (2010) Does environmental performance affect financial performance? A meta-analysis. Ecol Econ 70(1):52-59

51. Jang SH (2013) The offensive framework of resource based view (RBV): inhibiting others from pursuing their own values. J Manag Strateg 4(1):62-69

52. Junquera B, Barba-Sánchez V (2018) Environmental proactivity and firms' performance: mediation effect of competitive advantages in Spanish wineries. Sustainability 10(7):2155

53. Jarvis CB, MacKenzie SB, Podsakoff PM (2003) A critical review of construct indicators and measurement model misspecification in marketing and consumer research. J Consum Res 30(2):199-218

54. Karagozoglu N, Lindell M (2000) Environmental management: testing the win-win model. J Environ Plan Manag 43(6):817-829

55. King AA, Lenox MJ (2001) Does it really pay to be green? An empirical study of firm environmental and financial performance: an empirical study of firm environmental and financial performance. J Ind Ecol 5(1):105-116

56. Karim S, Mitchell W (2000) Path-dependent and path-breaking change: reconfiguring business resources following acquisitions in the US medical sector, 1978-1995. Strateg Manag J 21(10-11):1061-1081

57. Klassen RD, Whybark DC (1999) The impact of environmental technologies on manufacturing performance. Acad Manag J 42(6):599-615

58. Lucas MT (2010) Understanding environmental management practices: integrating views from strategic management and ecological economics. Bus Strateg Environ 19(8):543-556

59. Lee JW, Kim YM, Kim YE (2018) Antecedents of adopting corporate environmental responsibility and green practices. J Bus Ethics 148(2):397-409

60. Lin R, Tan K, Geng Y (2013) Market demand, green product innovation, and firm performance: evidence from Vietnam motorcycle industry. J Clean Prod 40(2013):101-107

61. López-Gamero M, Molina-Azorín J, Claver-Cortés E (2009) The whole relationship between environmental variables and firm performance: competitive advantage and firm resources as mediator variables. $J$ Environ Manag 90(10):3110-3121

62. May DR, Flannery BL (1995) Cutting waste with employee involvement teams. Bus Horiz 38(5):28-38
63. Margerum RD (1995) Integrated environmental management: moving from theory to practice. J Environ Plan Manag 38(3):371-392

64. Mishra S, Suar D (2010) Does corporate social responsibility influence firm performance of Indian companies? J Bus Ethics 95(4):571-601

65. Mardani A, Streimikiene D, Zavadskas EK, Cavalaro F, Nilashi M, Jusoh A, Zare H (2017) Application of structural equation modelling (SEM) to solve environmental sustainability problems: a comprehensive review and meta-analysis. Sustainability 9(10):1814

66. Nunnally JC, Bernstein IH (1994) Psychometric theory (McGraw-Hill series in psychology), vol 3. McGraw-Hill, New York

67. Nunnally JC, Bernstein IH, Berge JMF (1967) Psychometric theory, 2nd edn. McGraw-Hill, New York

68. Orlitzky M, Schmidt F, Rynes S (2003) Corporate social and financial performance: a meta-analysis. Organ Stud 24(3):403-441

69. Podsakoff P, Organ D (1986) Self-reports in organizational research: problems and prospects. J Manag 12(4):531-544

70. Podsakoff P, Mackenzie S, Lee J, Podsakoff N (2003) Common method biases in behavioural research: a critical review of the literature and recommended remedies. J Appl Psychol 88(5):879-903

71. Porter ME (2007) National economic strategy: Libya's moment for action. Monitor Company Group, New York

72. Priem RL, Butler JE (2001) Is the resource-based" view" a useful perspective for strategic management research? Acad Manag Rev 26(1):22-40

73. Porter ME, Van der Linde C (1996) Green and competitive: ending the stalemate. Harv Bus Rev 73:121-134

74. Poole MS, Van de Ven AH (1989) Using paradox to build management and organization theories. Acad Manag Rev 14(4):562-578

75. Porter M, Yegin D (2006) National economic strategy: an assessment of the competitiveness of the Libyan Arab Jamahiriya. The General Planning Council of Libya, Cera

76. Rao P, Holt D (2005) Do green supply chains lead to competitiveness and economic performance? Int J Oper Prod Manag 25(9):898-916

77. Rossiter JR (2002) The C-OAR-SE procedure for scale development in marketing. Int J Res Mark 19(4):305-335

78. Russo MV, Fouts PA (1997) A resource-based perspective on corporate environmental performance and profitability. Acad Manag J 40(3):534-559

79. Ray G, Barney JB, Muhanna WA (2004) Capabilities, business processes, and competitive advantage: choosing the dependent variable in empirical tests of the resource-based view. Strateg Manag J 25(1):23-37

80. Rubashkina Y, Galeotti M, Verdolini E (2015) Environmental regulation and competitiveness: empirical evidence on the porter hypothesis from European manufacturing sectors. Energy Policy 83:288-300

81. Rexhäuser S, Rammer C (2014) Environmental innovations and firm profitability: unmasking the Porter hypothesis. Environ Resour Econ 57(1):145-167

82. Saridogan M (2012) The impact of green supply chain management on transportation cost reduction in Turkey. Int Rev Manag Mark 2(2):112-121

83. Sekaran U (2006) Research Methods for Business: Research Methods for Business, 4th Edn. Translation of Kwan Men Yon. Salemba Empat, Jakarta

84. Springate SD (2011) The effect of sample size and bias on the reliability of estimates of error: a comparative study of Dahlberg's formula. Eur J Orthod 34(2):158-163

85. Sarkis J, Cordeiro J (2001) An empirical evaluation of environmental efficiencies and firm performance: pollution prevention versus end-ofpipe practice. Eur J Oper Res 135(1):102-113

86. Sharma S (2000) Managerial interpretations and organizational context as predictors of corporate choice of environmental strategy. Acad Manag J 43(4):681-697

87. Sharma S (2001) Different strokes: regulatory styles and environmental strategy in the North-American oil and gas industry. Bus Strateg Environ 10(6):344-364

88. Sharma S, Vredenburg H (1998) Proactive corporate environmental strategy and the development of competitively valuable organizational capabilities. Strateg Manag J 19(8):729-753

89. Sapnas KG, Zeller RA (2002) Minimizing sample size when using exploratory factor analysis for measurement. J Nurs Meas 10(2):135-154

90. Shrivastava P (1995) Environmental technologies and competitive advantage. Strateg Manag J 16(S1):183-200 
91. Stevens JP (1984) Outliers and influential data points in regression analysis. Psychol Bull 95(2):334

92. Van Berkel R (2007) Eco-efficiency in primary metals production: context, perspectives and methods. Resour Conserv Recycl 51(3):511-540

93. Wagner M (2003) An analysis of the relationship between environmental and economic performance at the firm level and the influence of corporate environmental strategy choice. Unpublished PhD thesis, Universität Lüneburg, Germany

94. Wagner M (2005) How to reconcile environmental and economic performance to improve corporate sustainability: corporate environmental strategies in the European paper industry. J Environ Manag 76(2):105-118

95. Wagner M (2007) Integration of environmental management with other managerial functions of the firm: empirical effects on drivers of economic performance. Long Range Plan 40(6):611-628

96. Watson SC (1998) A primer in survey research. J Contin High Educ 46(1):31-40

97. Wernerfelt B (1984) A resource-based view of the firm. Strateg Manag J 5(2):171-180
98. Wernerfelt B (2011) The use of resources in resource acquisition. J Manag 37(5):1369-1373

99. Winter SG (2003) Understanding dynamic capabilities. Strateg Manag J 24(10):991-995

100. Zhu Q, Sarkis J (2004) Relationships between operational practices and performance among early adopters of green supply chain management practices in Chinese manufacturing enterprises. J Oper Manag 22(3):265-289

101. Zutshi A, Sohal A (2004) Environmental management system adoption by Australasian organisations: part 1: reasons, benefits and impediments. Technovation 24(4):335-357

\section{Publisher's Note}

Springer Nature remains neutral with regard to jurisdictional claims in published maps and institutional affiliations.

\section{Submit your manuscript to a SpringerOpen ${ }^{\circ}$ journal and benefit from:}

- Convenient online submission

- Rigorous peer review

- Open access: articles freely available online

- High visibility within the field

Retaining the copyright to your article

Submit your next manuscript at $\boldsymbol{\nabla}$ springeropen.com 